\title{
EFFECTS OF ZINC, SELENIUM AND VITAMIN E INJECTIONS ON THE CONCENTRATION OF FATTY ACIDS, CONJUGATED LINOLEIC ACID (CLA) ISOMERS AND CHOLESTEROL IN OSSIMI EWES BLOOD AND MILK
}

\author{
A.A. Baiomy and A.I.A. Suliman \\ Animal production Department, Faculty of Agriculture, South Valley University, Qena, Egypt. \\ Animal Production Research Institute, Department of Animal Nutrition, Agriculture Research \\ Center, Dokki, Egypt.
}

\section{SUMMARY}

The present study was carried out at the Experimental farm of Animal Production Department, Faculty of Agriculture, South Valley University, Qena, Egypt during the period from June to October 2010. The study was conducted on 30 Ossimi ewes divided randomly into two groups each of 15 animals: Group 1 is control $\left(G^{1}\right)$ and group 2 is experimental group $\left(G^{2}\right)$. On thirty of day before lambing, then on day ${ }^{1}$, days ${ }^{21}$ and days ${ }^{42}$ post lambing all ewes from group $\left(G^{2}\right)$ were given

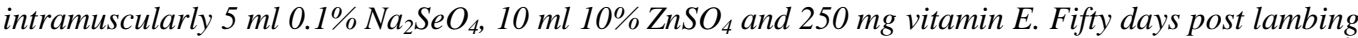
the concentration of CLA in milk sample ( 0.66 of the fatty aced sum) was found higher $(P<0.05)$ in $G^{2}$. However, cholesterol content was lower in $\left(G^{2}\right)$ than in $\left(G^{1}\right)(10.7 \mathrm{vs} / 14.22 \mathrm{mg} / 100 \mathrm{ml})$. The differences in blood plasma cholesterol were significant $(P<0.01)$, the figures were 3.78 and $3.01 \mathrm{mmo1/l}$, respectively, while the high density lipoprotein ( $H D L$ rose up in $G 2$ by $15.47 \%$ as compared in $\left(G^{1}\right)$. However the tri acid glycerol trended oppositely, which to $18.52 \% G^{2}$. It could be concluded that the pre- and post-partum intramuscular injections of $\mathrm{Se}, \mathrm{Zn}$ and vitamin E improved the lipid profile of milk.

Keywords: zinc, selenium, vitamin E, Polyunsaturated fatty acids (PUFA), Conjugated Linolic Acid (CLA) isomers, cholesterol, ewes milk

\section{INTRODUCTION}

The quality of milk fat has been extensively studied in relation to the type of feed, primarily in cows and ewes. Special attention is given to fatty acids that could play a positive role for human health, such as butyric acid, oleic acid, $\mathrm{C} 18$ to $\mathrm{C} 22$ polyunsaturated fatty acids (PUFA) Conjugated Linoleic Acid (CLA) (Chilliard et al., 2001). Isomers of Conjugated Linoleic Acid (CLA) found in ruminants' milk and meats are products of incomplete biohydrogenation of unsaturated fatty acids by rumen bacteria Butyrivibrio fibrisolvens (Kepler et al., 1966). CLA refers to a mixture of positional and geometric isomers of octadecadienoic (linoleic) acid with conjugated double bonds. The most extensively investigated CLA isomer is cis-9,trans-11 octadecadienoic acid, which is thought to be biologically active (Chin et al., 1992, Bessa et al.,2000). Zinc is a micro-mineral involved in various processes of animal metabolism. Since it was originally demonstrated that zinc is necessary for healthy growth rats (Underwood and Somers, 1977), the role of zinc in the animal organism began to gain special attention. Zinc participates actively in protein synthesis and carbohydrate metabolism. The discovery that the enzyme carbonic anhydrase contains $0.33 \%$ of zinc in its molecule (Underwood and Somers, 1977) is considered the first acceptable explanation of the mechanism of action of this element. After that, many other enzymes have been identified as containing zinc: alcohol dehydrogenase, carboxipeptidase and DNA-polymerase, this latest being fundamental in cell division process. This mineral stabilizes the quaternary structure of enzymes and large quantities of zinc were found to provide stability to the structures of RNA, DNA and ribosomes (Mc Dowell, 1992). $\mathrm{Zn}$ superoxide dismutase ( $\mathrm{ZnSOD)}$ is a dietary factor, which contributes to the antioxidant defence system (Morrissey et al. 1998). Some studies suggest that $\mathrm{Zn}$ content in diets of dairy cows can modify the level of blood lipids, as lower levels of $\mathrm{Zn}$ in the diet increase the lipid oxidation rate in the liver (Roussel et al.,1993). In most studies reviewed no adverse effects occurred when dietary Zn concentration was below 600 PPM. The requirement should be 46 PPM. Many factors influence $\mathrm{Zn}$ toxicity and dietary $\mathrm{Pb}, \mathrm{Cu}$ deficiency. Marginal Se intake exacerbates it, while soybean protein appears to protect against excess $\mathrm{Zn}$ compared with casein. Details of the toxic effects of $\mathrm{Zn}$ have been 
reviewed .Selenium is implicated in antioxidant functions, and Se-cysteine is essential in the active centres of Se-enzymes that carry out redox reactions, glutathione peroxidase (GPx), thyroid hormone deiodinase families and thioredoxinreductase (Tapiero et al., 2003). In several studies using rats, it was found that the content of polyunsaturated fatty acids (PUFA), especially in serum cholesterol esters and phospholipids were positively correlated with Se concentration in the diet (Crespo et al., 1995). Czauderna et al. (2004) suggested that the interaction between Se and the CLA isomers mixture protected CLA from peroxidation damage in muscles and increased the level of CLA in the muscles of rats. Supplementing the cows with selenium significantly decreased the level of cholesterol in blood plasma, including HDL and LDL lipoproteins (Brzóska and Brzóska, 2004). Reklewska et al. (2002) indicated that supplementing the diet with minimum doses of linseed and mineral mixture $\mathrm{Mg}, \mathrm{Fe}, \mathrm{Cu}, \mathrm{Co}$, $\mathrm{Mn}, \mathrm{Zn}, \mathrm{Se}, \mathrm{Cr}, \mathrm{Ca})$ significantly increases CLA isomers and decreases cholesterol content in cows milk. Vitamin $\mathrm{E}$ is primarily active as an antioxidant protecting polyunsaturated fatty acids in in vivo and post-mortem animal tissues and muscle nutrients from free-radical attack (Morrissey et al., 1994). The aim of the present experiment was to check the feasibility of decreasing the cholesterol level of blood and milk and increasing the CLA level of ewes milk by applying intramuscular pre- and postpartum injections of $\mathrm{Zn}$, Se and vitamin $\mathrm{E}$.

\section{MATERIALS AND METHODS}

This study was carried out at the Experimental farm of Animal Production Department, Faculty of Agriculture, South Valley University, Qena, Egypt where there is a prevailing tropical climate. The experiment was conducted on 30 Ossimi ewes divided randomly into two groups: control $(\mathrm{G} 1)$ and experimental $(\mathrm{G} 2)$, each of 15 animals. On thirty day before lambing, and then on day one, week three and week six after lambing all 15 ewes from group $\mathrm{G} 2$ received intramuscular injections with $5 \mathrm{ml} 0.1 \% \mathrm{Na}_{2} \mathrm{SeO}_{4}(2.09 \mathrm{mg}$ $\mathrm{Se}), 10 \mathrm{ml} \mathrm{10 \%} \mathrm{ZnSO}_{4}(227 \mathrm{mg} \mathrm{Zn})$ and 250 $\mathrm{mg}$ vitamin $\mathrm{E}(\alpha-$ tocopherol).Both groups were kept with their lambs under the same management conditions eight weeks post lambing. Feeding was based on: maize silage, alfalfa hay, concentrate mixture (Soybean meal $8 \%$, Yellow maize $36.5 \%$, sunflower meal $16 \%$, Barley meal $20 \%$, Wheat bran $16 \%$, Calcium carbonate $2 \%$, Sodium chloride $1 \%$ and Vitamin-mineral mixture $0.5 \%$ ). The daily dry matter (DM) intake per ewe during pregnancy was $0.51 \mathrm{~kg}$ from alfalfa hay, 0.67 $\mathrm{kg}$ from maize silage and $0.86 \mathrm{~kg}$ from concentrate feed mixture while during lactation period were $0.68,0.67$ and $1.04 \mathrm{~kg} /$ head /day respectively. The declared content of $\mathrm{Zn}$ and Se in the mineral premix was 6000 PPM and 12 PPM, respectively. Milk samples were taken at week 1 and week7 post lambing, following the injection of $1 \mathrm{ml}$ oxytocin per ewe to stimulate milk let-down. Proximate analysis of feeds was performed using standard methods A.O.A.C. (2005) The level of metabolizable energy of feed was calculated on the basis of the results of proximate chemical analyses using the equation recommended by (MAFF, 1975). The concentrations of SFA, MUFA, Polyunsaturated Fatty Acids (PUFA) and (CLA) were measured in milk. To determine fatty acids milk samples were freeze-dried and extracted with chloroformmethanol-water mixture (4:2:1.v/v). Hydrolization and derivatization reaction was carried out according to Czauderna at al. (2001). The derivatized samples were filtered through $0.2 \mu \mathrm{m}$ membrane filter (Whatman) and the filtrates injected on two chromatographic column Spheri-5 RP-18, 5 $\mu \mathrm{m}, 220 \times 4.6 \mathrm{~mm}$ (Perkin Elmer, USA). The CLA isomer mixture standard (the cis-9,trans11 and trans-10,cis-12) of CLA and other fatty acid standards were provided by SIGMA (USA).The blood was withdrawn six weeks after lambing. To determine total HDL (highdensity lipoprotein), cholesterol and Triacylglycerol (TAG) in blood plasma determined using Enzyme-linked tests 12 ppm . To determinate cholesterol in milk, samples were saponified and extracted with hexane according to Fletouris et al. (1998). Total cholesterol in blood serum was determined colorimetrically according to Searcy and Berquist (1960) . Zn content in feeds was determined by atomic absorption spectrometry. Samples $(0.5 \mathrm{~g})$ were mineralized in a mixture of $5 \mathrm{ml} \mathrm{HNO}_{3}$ and $1 \mathrm{ml} \mathrm{H}_{2} \mathrm{O}_{2}$ in hermetic highpressure vessels by heating in microwave oven. Total Se content was determined by flame (air-acetylene) atomic absorption spectrometry using hydrogen generation system. Selenium hydride was generated with $\mathrm{NaBH}_{4}$. Hallow cathode lamp (196.0 nm) with deuterium background correction was used.

\section{Statistical analysis:}

Data were statistically analyzed using SAS (2001), Duncan Multiple range Test was used to compare the differences among means (Duncan, 1955). The effect of Zinc, Selenium and vitamin $\mathrm{E}$ injections were considered to analyze milk traits and chemical composition of blood Ossimi ewe. The following model 
used for milk traits and chemical composition of blood Ossimi ewe was as follows:

Yik $=\mathrm{U}+\mathrm{B} \mathrm{i}+$ eik $\quad$ where:

Yijk $=$ The trait of study

$\mathrm{U}=$ The overall mean;

$\mathrm{Bi}=$ The fixed effect of ith Zinc, Selenium

and vitamin E injections;

Eijk $=$ random error

\section{RESULTS AND DISCUSSION}

The results of proximate analyses of feeds and their nutritive value, as well as $\mathrm{Zn}$ and Se contents of DM are shown in Table 1. Daily Se intake per ewe from feeds and mineral premix during pregnancy and lactation period amounted 0.39-0.44 mg while $\mathrm{Zn}$ from 115123 mg. However, National Research Council (NRC, 1992) suggested that Se requirements for sheep vary from 0.1 to 0.2 PPM of feed DM. Mc Dowell (1992) suggested that dietary may have some beneficial effects when it's above those generally accepted levels.

Injecting $\mathrm{Se}, \mathrm{Zn}$ and vitamin $\mathrm{E}$ intramuscular before and after lambing of ewes was effective in increasing the contents of these nutrients in milk (Gabryszuk et al., 2005). However, when the Se level of blood plasma was within the normal range, injecting additional $\mathrm{Se}$ and vitamin $\mathrm{E}$ has adverse effects, decreasing fertility and lamb body live weight at birth (Gabryszuk, 1994).

In comparison to the control (G1), four intramuscular injections of $\mathrm{Se}$ (each of 2.09 $\mathrm{mg}$ ), $\mathrm{Zn}$ ( each of $227 \mathrm{mg}$ ) and vitamin E (250 $\mathrm{mg}$ ) applied in group (G2) led to a significant decrease in the cholesterol content of milk and total cholesterol of blood plasma with simultaneously higher levels of HDL fraction (Table 2). Simultaneously the concentration of Triacylglycerol (TAG) of blood plasma in group (G2) was lower than in control ewes (Table 2)

Results of proximate analysis of feeds and metabolizable energy ( $\mathrm{MJ} / \mathrm{Kg} \mathrm{DM})$ are shown in Table1.

The Selenium (Se) content of crops below $0.1 \mathrm{ppm}$ is the level considered adequate for preventing deficiency in sheep (NRC, 1983).

The most commonly noticed lesion in sheep resulting from an inadequate supply of Selenium is degeneration of the cardic and skeletal musculature (white muscle disease), but unthriftiness, early embryonic death, and periodontal disease are also signs of a possible Selenium deficiency (Underwood, 1981).

Supplementation with $0.1 \mathrm{mg} \mathrm{Se} / \mathrm{Kg} \mathrm{DM}$ (as sodium selenite) in the diet of ewes during gestation, through weaning consistently provided essentially complete protection against white muscle disease in their lambs (Schubert et al., 1961).

In the present study daily selenium intake per ewe from diet during pregnancy and lactation period were $0.27 \mathrm{mg} / \mathrm{Kg} \mathrm{DM}$ and $0.30 \mathrm{mg} / \mathrm{kg} \mathrm{DM}$ in addition to premix containing 12 PPM selenium, while the Zinc was $55.56 \mathrm{mg} / \mathrm{Kg} \mathrm{DM}$ and $63.43 \mathrm{mg} / \mathrm{Kg} \mathrm{DM}$ during pregnancy and lactation period respectively and from premix concentration 6000 PPM.

Although (Davies et al., 2006), showed that the maximum tolerable level of inorganic Se for sheep is much higher than $2 \mathrm{mg} / \mathrm{kg} \mathrm{DM}$ as suggested earlier, feeding up to $12 \mathrm{mg}$ sodium selenite $/ 1 \mathrm{~kg}$ DM of feed, to ewes under the stress status of production (i.e gestation and lactation) for 72 weeks did not produce any clinical or pathogenic signs of Se intoxication .

Zinc supplementation of 40 PPM to the diet of Pregnant and lactating ewes has yet to be determined the few studies that have been conducted indicated that the lactating ewe is clearly susceptible to zinc deficiency, but whether zinc is necessary for normal parturition in sheep as it is in rats is still unclear (Moir, 1983).

The suggested minimum requirements are $20 \mathrm{mg} \mathrm{Zn/} \mathrm{Kg} \mathrm{DM} \mathrm{for} \mathrm{growth} \mathrm{and} 33 \mathrm{mg} \mathrm{Zn} \mathrm{/}$ $\mathrm{Kg} \mathrm{DM}$ for maintenance of normal reproductive function in males and for pregnancy and lactation in females. Diets high in calcium (1.2 to 1.8 percent calcium) have been reported to adversely affect Zinc utilization (Mills and Dalgarno,1967) .

NRC (1992) suggested that the requirements of sheep for $\mathrm{Zn}$ vary from 20 to $33 \mathrm{mg} / \mathrm{Kg}$ DM of feed.

Although Mc Dowell (1992) showed that ruminants overt $\mathrm{Zn}$ toxic sis first appears when levels around 1000 PPM are in corporated into a natural - ingredient diet .

Injecting $\mathrm{Se}, \mathrm{Zn}$ and vitamin $\mathrm{E}$ intera muscular before and after lambing were effective in increasing the contents of these nutrients in milk (Gabryszuk et al., 2005). However, when the Se level of blood plasma was within the normal range, injecting both $\mathrm{Se}$ and V. E decreased fertility and lamb body live weigh at birth (Gabryszuk, 1994).

In comparison to the control $\left(\mathrm{G}^{1}\right)$, three intra muscular injections of Se (each $2.09 \mathrm{mg}$ ), $\mathrm{Zn}$ (each of $227 \mathrm{mg}$ ) and vitamin E (250 mg) applied in $\left(\mathrm{G}^{2}\right)$ led to significant decrease in the cholesterol content of milk $10.7 \mathrm{mml} / 100$ $\mathrm{ml}$ in $\left(\mathrm{G}^{2}\right)$ vs $14.24 \mathrm{mml} / 100 \mathrm{ml}$ in $\left(\mathrm{G}^{1}\right)$. The same trend was observed. Simultaneously the concentration of TAG of blood plasma in (G2) was lower than (G1) .

On the contrary high density lipproteinsn (HDL) recorded higher levels for (G2) than 
(G1) the figures were $0.98+0.13$ vs $0.85+0.14$ $\mathrm{mmol} / \mathrm{L}$ (Table 2). These results agree with the findings of Brz oska and Brz oska (2004) and Reklewska et al., (2002).

(Table 3) exhibits the concentration of SFA $\%$, MUFA $\%$, PUFA \% and CLA $\%$ in milk at week 1 and week 7 .

Saturated fatty Acids (SFA) showed higher $\%$ at week 1 and week 7 in (G1) compared with week 7 in (G1), the figures were $71.3 \%$ and $74.4 \%$ vs $70.4 \%$ and $72.2 \%$, respectively, while the enhancement was $2.95 \%$ in the decline of SFA.

Monounsaturated fatty Acids (MUFA\%) $22.2 \%$ and $20.2 \%$ compound for (G1) compared with $22.4 \%$ and $21.5 \%$ respectively, for week 1 and week 7 , therefore the enhancement in MUSFA for week 1 and week 7 were $0.9 \%$ \& $6.44 \%$, respectively. While Polyunsaturated Fatty Acids (PUFA) were raised from $6.4 \%$ to $7.2 \%$ in week 1 and from $5.4 \%$ to $6.3 \%$ in week 7 . Therefore the enhancement of (PUFA) in week 1 and week 7 were $12.51 \%$ and $16.62 \%$ respectively.

This simultaneously showed in Conjugated Linolic Acids Isomers(CLA), which enhanced by $42.59 \%$ in (G2) when compared with (G1) in week 1 , while in week 7 the enhancement was $53.49 \%$ in (G2) when compared with (G1), (Table 3).

These findings agree with those found by Reklewska et al. (2002), who reported significant increases in CLA and decreases in cholesterol.

Falkowska et al. (2000) showed that supplementation of a diet with Se and vitamin E significantly increased HDL fraction in the blood of cows from 0.440 to $0.552 \mathrm{mmol} / \mathrm{l}$. Brzóska and Brzóska (2004) observed that when the level of dietary Se was increased from 0.04 to $0.48 \mathrm{mg} / \mathrm{kg} \mathrm{DM}$, the cholesterol content of blood plasma in cows declined from 228.6 to $183.9 \mathrm{mg} / \mathrm{dl}$, with simultaneous decreases in HDL and LDL. The level of $\mathrm{Zn}$ ranging from 39 to $59 \mathrm{mg} / \mathrm{kg} \mathrm{DM}$ of the diet of dairy cows did not affect cholesterol or other metabolite levels in blood plasma or milk.

(Brz óska and Kowalczyk, 2002). The long-chain n-3 fatty acids are known to be a factor in decreasing the LDL content of the liver, which at a declining tendency in blood plasma, could promote the increase of HDL blood plasma content (Brzóska and Kowalczyk, 2002).

While concentrations of CLA in milk was higher in (G2) (0.77 vs 0.54$)$ in $(\mathrm{G} 1) \mathrm{mmol} / \mathrm{L}$ (Table 3), Reklewska et al. (2002) reported significant increases in CLA and decreases in the cholesterol content of cows 'milk, fed a diet with minimum doses of linseed and a mineral bioplex mixture $(\mathrm{Mg}, \mathrm{Fe}, \mathrm{Cu}, \mathrm{Co}, \mathrm{Mn}, \mathrm{Zn}, \mathrm{Se}$,
$\mathrm{Cr}, \mathrm{Ca}$ ). In an earlier study (Gabryszuk et al. 2007) which demonstrated that Se, Zn and vitamin $\mathrm{E}$ administered orally to growing ramlambs induced a decrease in cholesterol content of blood and meat, and led to increased CLA isomer levels in meat and liver. Emanuelson and Bertilsson (1995) reported a tendency to increase oxidation of milk fat when linseed was added to a cows' diet. Spontaneous oxidation of milk fat may occur at a low concentration of milk antioxidants. Since increased dietary concentration of antioxidants may lead to improved oxidative stability of milk fat (Niki et al., 1989) it seemed worth trying to produce milk of increased content of antioxidants as well as of some functional fatty acids. We suggest that the interactions between $\mathrm{Se}, \mathrm{Zn}$ and vitamin $\mathrm{E}$ are factors which can modulate desaturase and chain elongase activity as well as inhibit fatty acid $\beta$ - oxidation in mammary glands. The genetically determined ability of the subcellular membrane to assimilate and store peroxidation antagonists such as vitamin $\mathrm{E}$, GSH-Px, catalase and superoxide dismutase. Crespo et al. (1995) reported that the concentration of PUFA was positively correlated with the level of Se in diets of rats. The cis-9,trans- 11 CLA found in ruminants milk and meat is an intermediate in the biohydrogenation of linoleic acid (cis-9,cis-12 C18:2) to stearic acid (C18:0) - Bessa et al. (2000) The major part of conjugated linoleic acids (cis-9,trans-11 C18:2) is synthesized in the ruminant tissues and particularly in the mammary glands by the desaturation of transvaccenic acid (trans-11 C18:1) resulting from the action of the stearoyl-CoA desaturaze (SCD). The introduction of cis-double bond is catalysed by the set of microsomal electrontransport proteins composed sequentially of NADH cytochrome b5 reductase, cytochrome $\mathrm{b5}$, and the terminal SCD. Stearoyl-CoA desaturase is the rate-limiting component in this reaction. Its activity is regulated by different factors such as diet, hormones, temperature, metals, peroxisomal proliferators, vitamin A, and developmental processes (Ntambi, 1999; Miyazaki and Ntambi, 2003). More than $80 \%$ of cis-9,trans-11 CLA in milk is produced endogenously by $\Delta 9$-desaturase from trans-11 C18:1 in the mammary gland. Cows on the same diet have different milk fat cis-9,trans-11 CLA concentrations that may be partially explained by differences in $\Delta 9$ desaturase activity between cows . Increasing the activity of $\Delta 9$-desaturase in the mammary gland may offer greater potential for enhancing the cis-9,trans-11 CLA content of milk fat (Lock and Garnsworth 2002). We presume that supplementation of $\mathrm{Se}, \mathrm{Zn}$ and vitamin $\mathrm{E}$ can 
regulate activity of SCD. We also suggest that dietary $\mathrm{Se}, \mathrm{Zn}$ and vitamin $\mathrm{E}$ decreased $\beta$ oxidation of the CLA isomers in mammary gland. It can be hypothesized that the $\mathrm{Se}$ (as $\mathrm{Na} 2 \mathrm{SeO} 4), \mathrm{Zn}$ and vitamin $\mathrm{E}$ as strong antioxidants, have a protective effect against per oxidation damage in CLA isomers metabolism

This study demonstrated that Se, Zn and vitamin $\mathrm{E}$ administered intramuscularly to pregnant and lactating ewes induced a decrease in cholesterol content of blood and milk, and led to increased the CLA isomers level in milk.

Based on the above observation, it is suggested that the intramuscular administration of Se, $\mathrm{Zn}$ and vitamin $\mathrm{E}$ improved the lipid profile of ovine milk which should be evaluated for consumer uptake/acceptance .

\section{REFERENCES}

AOAC, 2005. Official Methods of Analysis of the Association of Official Analytical Chemist. 18th Edn., Horwitz William Publication, Washington, DC., USA.

Besa, R.J.B., J. Santos-Silva, J.M.R. Ribeiro, and A.V. Portugal, 2000. Reticulo-rumen bio-hydrogenation and the enrichment of ruminant edible products with linoleic acid conjugated isomers. Livestock Production Science 63, 201-211.

Brz, óska, F. and B. Brz óska, 2004. Effect of dietary selenium on milk yield of cows and chemical composition of milk and blood. Annals of Animal Science 4, 57-67.

Brz óska, F., J. Kowalcz yk, 2002. Milk yield, composition and cholesterol level in dairy cows fed rations supplemented with zinc and fatty acid calcium salts. Journal of Animal and Feed Sciences 11, 411-424.

Chin, S.F., W. Liu, J.M. Stork Son, Y.L. Ha, M.W. Pariza, 1992. Dietary sources of dienoic isomers of linoleic acid, a newly recognized class of ant carcinogens. Journal of Food Composition and Analysis 5, 185-197.

Crespo, A.M., M.A. Reis, M.J. Lanca, 1995. Effect of selenium supplementation on polyunsaturated fatty acids in rats. Biological Trace Element Reserch 47, 335341.

Czauderna, M., J. Kowalcz yk, G. Chojecki, 2001. An improved method for derivatization of fatty acids for liquid chromatography. Journal of Animal and Feed Sciences 10(2), 369-375.

Czauderna, M., J. Kowalcz yk, K.M. Nied źwiedzka, I. Wąsowska, B. Pastuszewska, 2004. Conjugated linoleic acid (CLA) content and fatty acids composition
Davis, P.A., L.R. McDowel, N.S.Wilkinson, C.D. Burgelt, R.Van Alst yne, R.N. Weldon, T.T. Marshal, 2006. Tolerance of organic selenium by range-type ewes during gestation and lactation. Journal of Animal Science 84, 660-668.

Rousel,A.M., M.j.Richarrd, A. Ravel, A.Vilet, Y.J. Alar,1993.Influence of Zinc deficiency on rat fatty acid distribution and peroxidation. In : Anke A., Meissner D., Mills C.F. (Eds.). Proceedings of the $8^{\text {th }}$ International Symposium on Trace Elements in Man and Animal - THEMA 8. Verlag Media Turistic, 571-572.

Duncan , D.B.,1955. Multiple ranges and multiple F-test. Biometrics, 11:1-42.

Emanuelson M., J. Bertilson, 1995. The effect of feeding on milk fat content and fatty acid composition. In: Mantere-Alhonen S., Maijala S., (Eds.), Milk in nutrition effects of production and processing factors. Proceedings of NJF/NMR seminar No. 25, Turku, Finland.

Falkowska, A., D. Minakowski, J. Tywo ńczuk, 2000. The effect of supplementing rations with selenium and vitamin $\mathrm{E}$ on biochemical parameters in blood and performance of cows in the early stage of lactation. Journal of Animal and Feed Sciences 9, 271-282.

Fletouris. D.J., N.A. Botsoglou, I.E. Psomas, A.I Mantis., 1998. Rapid determination of cholesterol in milk and milk products by direct saponifification and capillary gas chromatography. Journal of Dairy Science 81, 2833-2840.

Gabr yszuk, M., 1994. The effect of selected minerals and vitamin $\mathrm{E}$ on the reproduction of the Polish Merino sheep. II Reproduction and rearing lambs. Animal Science Papers and Reports 12, 53-61.

Gabr yszuk, M., M. Czauderna, A. Baranowski, N. Strza łkowska, A. Jóźwik, J. Krz yżewski, 2007. The effect of diet supplementation with $\mathrm{Se}, \mathrm{Zn}$ and vitamin $\mathrm{E}$ on cholesterol, CLA and fatty acid contents of meat and liver of lambs. Animal Science Papers and Reports 25, 25-33.

Gabr yszuk, M., M. Czauderna, M.A. Gralak, Z. Antoszkiewicz, 2005. Effects of pre- and postpartum injections of $\mathrm{Se}, \mathrm{Zn}$ and vitamin $\mathrm{E}$ on their concentration in ewes milk. Journal of Animal and Feed Sciences 14, Suppl. 1, 255-258.

Kepler, C.R., K.P. Hirons, J.J. McNeill, S.B. Tove, 1966. Intermediates and products of the biohydrogenation of linoleic acid by Butyrivibrio fibrisolvens. Journal of Biological Chemistry 241, 1350-1354.

Lock, A.L., y.P.C. Garnsworth, 2002. Independent effects of dietary linoleic and 
linolenic fatty acids on the conjugated linoleic acid content of cows' milk. Animal Science 74, 163-176.

MAFF (Ministry of Agriculture, Fisheries and Food), 1975. Energy Allowances and Feeding System for Ruminants. London, Tech. Bull. No 33.

McDowel, L.R., 1992. Minerals in animal and human nutrition. Academic Press, Inc., San Diego, USA.

Mills, C. F., A. C. Dalgarno, R. B. Williams, and J. quanterman. 1967. Zinc deficiency and the Zinc requirements of calves and lambs. Br. J. Nutr. 21:731 - 768 .

Miyazaki, M., J.M. Ntambi, 1999. Role of stearoyl-coenzyme A desaturase in lipid metabolism. Prostaglandins, Leukotrienes and Essential Fatty Acids 68, 113-121.

Moir, R. J. .1979 Basic concepts of salphur nutrition Pp $93-108$ in proc 2 nd Ann. Int. Miner. Conf. St. Petersburg Bouch, Fla.

Morisy,P.A., P.B. Quin, y.P.J.A. Sheh, 1994. Newer aspects of micronutrients in chronic disease: vitamin E. Proceedings of the Nutrition Society 53, 571-582.

Motisy, P.A., y. P.J.A. Sheh, K. Galvin, y J.P. Ker, y .D.J. Buckle, 1998. Lipid stability in meat and meat products. Meat Science 49(1), S73-S86.

National Research Council 1983. Selenium in Nutrition. Washington, D.C., National Academy press.

National Research Council 1992., Zn in Nutrition. Washington, D. C., National Academy press.
Niki, E., Y. Yamamoto, M. Takahashi, E. Komuru, Y. Miyama, 1989. Inhibition of oxidation of biomembranes by tocopherol. Annals of the New York Academy of Sciences 570, 23-31.

Ntambi, J.M., 1999. Regulation of stearoylCoA desaturase by polyunsaturated fatty acids and cholesterol. Journal of Lipid Research 40, 1549-1558.

Reklewska, B., A. Oprz ądek, Z. Reklewski, L. Panicke, B. Kucz yńska, J. Oprz ądek, 2002.Alternative for modifying the fatty acid composition and decreasing the cholesterol level in the milk of cows. Livestock Production Science 76, 235-243.

SAS. 2001. SAS/STAT user's guide Release 8.2. Statistical Analysis System. SAS Institute Inc. Cary NC USA.

Searcy, R. L., L. M. Berquist, 1960. A new color reaction for the quantitation of serum cholesterol. Clinica Chimica Acta 5, 192199.

Tapiero, H., D. M. Townsend, K. D. Tew, 2003. The antioxidant role of selenium and selenocompounds. Biomedicine Pharmacotherapy 57, 134-144.

Underwood, E. J. 1981. the mineral Nutrition of livestock. Slough common wealth Agriculture Bureaux.

Underwood, E. J. and M. Somers, 1977. Zinc: trace elements in human and animal nutrition. New York: Academic, 196-242.

Table 1. Approximate Chemical analysis of feeds (g/kg/DM)

\begin{tabular}{lccc}
\hline Component & $\begin{array}{c}\text { concentrate } \\
\text { mixture }\end{array}$ & alfalfa hay & Maize silage \\
\hline Dry matter & 882 & 895 & 336 \\
In dry matter :- & & & \\
Crude protein & 168 & 195 & 88 \\
crude fibre & 163 & 267 & 261 \\
ether extract & 29 & 12 & 24 \\
crude ash & 75 & 122 & 98 \\
N-free extractives & 565 & 404 & 529 \\
Neutral detergent Fibre & 302 & 634 & 460 \\
Acid detergent fibre & 137 & 365 & 241 \\
ADL & 43 & 42 & 22 \\
Metabolizable Energy(MJ/kg) & 12.6 & 10.2 & 11.8 \\
Se (mg/kg DM) & 0.16 & 0.10 & 0.12 \\
Zn (mg/kg DM) & 29.4 & 15.1 & 33.7 \\
\hline
\end{tabular}


Table 2. Means \pm SE of cholesterol content of milk, and total cholesterol, HDL fraction and TAG contents of blood plasma of Ossimi ewes

\begin{tabular}{lcc}
\hline \multicolumn{1}{c}{ Item } & $\mathbf{G}^{\mathbf{1}}$ & $\mathbf{G}^{\mathbf{2}}$ \\
\hline Week7 Milk & & \\
cholesterol $(\mathrm{mg} / 100 \mathrm{~g})$ & $14.23 \pm 2.89$ & $10.6 \pm 1.96$ \\
Week 6 Blood & & \\
total cholesterol $(\mathrm{mmol} / \mathrm{l})$ & $3.79 \pm 0.60$ & $3.02 \pm 0.51$ \\
HDL (mmol/l) & $0.85 \pm 0.14$ & $0.98 \pm 0.13$ \\
TAG (mmol/l) & $0.54 \pm 0.09$ & $0.44 \pm 0.05$ \\
\hline HDL $=$ Highdensity lipoprotein & TAG $=$ triacylglycerol
\end{tabular}

Table 3. Means \pm SE of Fatty acid composition (\% of total fatty acids) of Ossimi ewes milk Item Week 1 Milk Week 7 Milk

\begin{tabular}{lllll}
\hline & \multicolumn{1}{c}{ G1 } & \multicolumn{1}{c}{ G2 } & \multicolumn{1}{c}{ G1 } & \multicolumn{1}{c}{ G2 } \\
SFA (\%) & $71.3 \pm 10.2$ & $70.4 \pm 17.4$ & $74.4 \pm 14.3$ & $72.2 \pm 22.8$ \\
MUFA (\%) & $22.2 \pm 16.6$ & $22.4 \pm 21.1$ & $20.2 \pm 16.6$ & $21.5 \pm 22.8$ \\
PUFA (\%) & $6.4 \pm 19.3$ & $7.2 \pm 28.8$ & $5.4 \pm 19.9$ & $6.3 \pm 7.3$ \\
CLA (\%) & $0.54 \mathrm{~b} \pm 19.9 \mathrm{~b}$ & $0.77 \mathrm{a} \pm 28.8 \mathrm{a}$ & $0.43 \mathrm{~b} \pm 24.3 \mathrm{~b}$ & $0.66 \mathrm{a} \pm 26.6 \mathrm{a}$ \\
\hline
\end{tabular}

${ }^{\mathrm{a}}$ and ${ }^{\mathrm{b}}$ means in the same row followed by different letters are significantly different $(\mathrm{p}<0.05)$.

PUFA=Polyunsaturated Fatty Acids . CLA= Conjugated Linolic Acid

MUFA=Monounsaturated fatty acids. SFA= Saturated fatty acids.

$$
\begin{aligned}
& \text { دراسة تأثير الحقن بعنصى الزتلك والسلينيوم وفيتامين هـ على تركيز الأحماض الاهنية والكلسترول فى }
\end{aligned}
$$

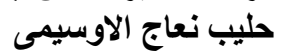

$$
\begin{aligned}
& \text { أحمد عبد الجليل بيومي، عبد الرحيم إدريس علي سليمان } \\
& \text { ا ـ كلية الزر اعة، جامعة جنوب الو ادي، قسم الإنتاج الحيو اني، كـ معهد بحوث الإنتاج الحيو اني، مركز البحوث الزراعية ، قسم } \\
& \text { تغذية الحيوان. }
\end{aligned}
$$

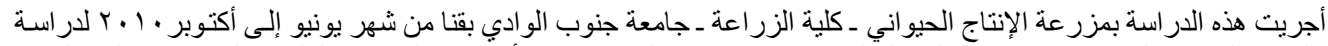

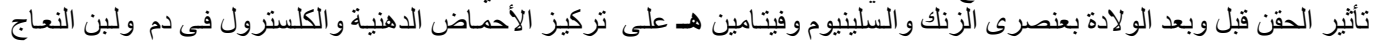

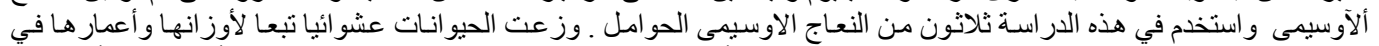

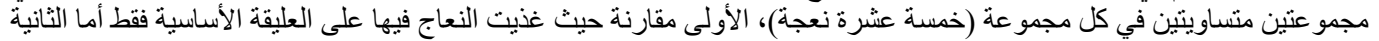

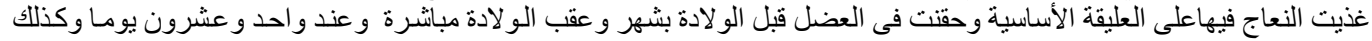

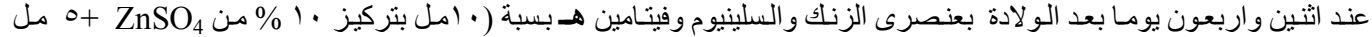

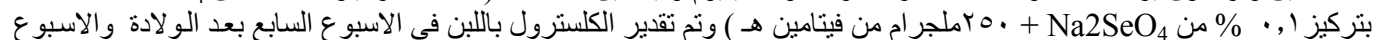

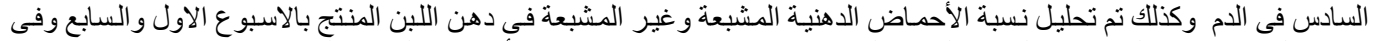

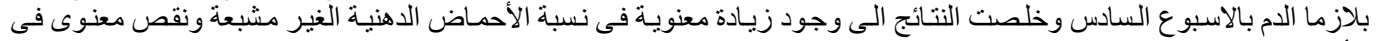

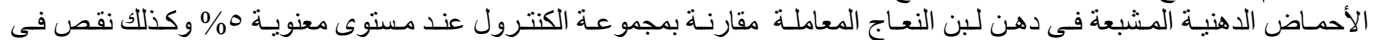

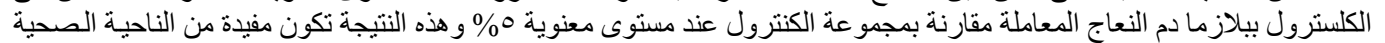

